Article

\title{
DnaK3 Is Involved in Biogenesis and/or Maintenance of Thylakoid Membrane Protein Complexes in the Cyanobacterium Synechocystis sp. PCC 6803
}

\author{
Adrien Thurotte ${ }^{1,2,+} \mathbb{C}$, Tobias Seidel ${ }^{1,+}$, Ruven Jilly ${ }^{1}$, Uwe Kahmann ${ }^{3}$ and Dirk Schneider ${ }^{1, * \mathbb{C}}$ \\ 1 Department of Chemistry, Biochemistry, Johannes Gutenberg University Mainz, 55128 Mainz, Germany; \\ adrienthurotte@netcourrier.com (A.T.); TobiasSeidel@gmx.net (T.S.); ruvenjilly@gmail.com (R.J.) \\ 2 Institute of Molecular Biosciences, Goethe University Frankfurt, Max-von-Laue Straße 9, \\ 60438 Frankfurt, Germany \\ 3 Department of Molecular Cell Biology, Bielefeld University, 33615 Bielefeld, Germany; ZUD@gmx.de \\ * Correspondence: dirk.schneider@uni-mainz.de; Tel.: +49-6131-39-25833 \\ + These authors contributed equally.
}

Received: 8 April 2020; Accepted: 28 April 2020; Published: 30 April 2020

\begin{abstract}
DnaK3, a highly conserved cyanobacterial chaperone of the Hsp70 family, binds to cyanobacterial thylakoid membranes, and an involvement of DnaK3 in the biogenesis of thylakoid membranes has been suggested. As shown here, light triggers synthesis of DnaK3 in the cyanobacterium Synechocystis sp. PCC 6803, which links DnaK3 to the biogenesis of thylakoid membranes and to photosynthetic processes. In a DnaK3 depleted strain, the photosystem content is reduced and the photosystem II activity is impaired, whereas photosystem I is regular active. An impact of DnaK3 on the activity of other thylakoid membrane complexes involved in electron transfer is indicated. In conclusion, DnaK3 is a versatile chaperone required for biogenesis and/or maintenance of thylakoid membrane-localized protein complexes involved in electron transfer reactions. As mentioned above, Hsp70 proteins are involved in photoprotection and repair of PS II in chloroplasts.
\end{abstract}

Keywords: chaperone; Hsp70; photosynthesis; thylakoid membrane biogenesis; photosystem maintenance; Synechocystis sp. PCC6803

\section{Introduction}

In plants and cyanobacteria, the biogenesis and dynamics of thylakoid membranes (TMs) is light-controlled [1,2]. In plants, proplastids develop into chloroplasts, involving the de novo formation of an internal TM network [3], and a developed TM network dynamically reorganizes in the light [4]. When the cyanobacterium Synechocystis sp. PCC 6803 (from here on: Synechocystis) is grown in the dark under light-activated heterotrophic growth (LAHG) conditions, where glucose is the only available energy source, Synechocystis cells exhibit reduced or even just rudimentary TMs [5,6]. However, after shifting dark-adapted cells into the light, the Synechocystis cells quickly rebuild a TM network and recover photosynthetic activity [5,7]. While dark-adapted Synechocystis cells do not harbor active photosystem II (PS II) complexes, complete photosynthetic activity is regained within $24 \mathrm{~h}$ after transferring dark-adapted cells into the light, and reappearance of photosynthetic electron transfer processes is coupled to the formation of internal TMs [7]. However, it is still enigmatic how the formation of internal TMs is controlled, both in chloroplasts and cyanobacteria, although some proteins that might be involved in this process have already been described previously [8]. These proteins include the inner membrane-associated protein of $30 \mathrm{kDa}$ (IM30, also known as Vipp1: The vesicle-inducing protein in plastids 1), Hsp70 (Heat shock protein 70) chaperones, dynamin-like proteins, a prohibitin-like protein, 
as well as YidC, a membrane protein integrase [9-16]. Nevertheless, while some proteins are probably more directly involved in TM formation, the structure and stability of TMs are also affected more indirectly by pathways, which control the biogenesis of lipids and/or cofactors, and, e.g., mutants defective in synthesis of chlorophyll or of the membrane lipid phosphatidylglycerol (PG) have severely reduced TM systems [17-20].

Molecular chaperones of the Hsp70 family are involved in multiple cellular processes, such as folding of newly synthesized proteins, protein disaggregation, prevention of protein misfolding, protein transport, or the control of regulatory protein functions [21]. The thus far best characterized Hsp70 chaperone is the DnaK protein of the bacterium Escherichia coli [22]. In cyanobacteria, at least two DnaK proteins, DnaK2 and DnaK3, are highly conserved, and most cyanobacteria contain an additional DnaK1 protein as well as further DnaK-like proteins $[15,23,24]$. While cyanobacterial genomes typically encode several DnaK chaperones together with multiple DnaJ (Hsp40) proteins, which serve as DnaK co-chaperones, the physiological function of this DnaK-DnaJ network in cyanobacteria is essentially not understood. In recent years, the physiological roles of individual DnaK and DnaJ proteins have been analyzed to some extent in the cyanobacteria Synechococcus sp. PCC 7942 and Synechocystis [16,24-26]. In Synechocystis, three DnaK proteins are expressed together with at least seven DnaJ proteins $[15,25]$. The two dnaK genes dnaK2 and dnaK3 are essential in Synechocystis, but not dnaK1 [15]. The DnaK2 protein has been classified as the canonical DnaK protein involved in cellular stress responses, and DnaK2 most likely functions together with S110897, the only type I DnaJ protein expressed in Synechocystis [24,25]. In line with this, deletion of the sllo897 gene resulted in a heat-sensitive phenotype [25]. However, interactions with other DnaJ proteins cannot be excluded, and in fact, the DnaK2 protein interacts and cooperates with the type II J protein DnaJ2 in Synechococcus sp. PCC 7942 [27].

In contrast to the remaining dnaJ genes, the dnaJ gene sll1933 (dnaJ3) could not be deleted in Synechocystis, indicating that the encoded DnaJ3 protein is essential [25]. The dnaK3 and dnaJ3 genes are organized in a conserved gene cluster in cyanobacteria, and a functional interaction of DnaK3 with DnaJ3 is assumed [28] DnaK3- and DnaJ3-homologs are encoded in essentially all cyanobacterial genomes, except in Gloeobacter violaceus PCC 4721, a cyanobacterium that lacks TMs [29,30]. Based on this observation it has been suggested that the physiological function of both proteins might be linked to TMs, and consequently, DnaK3 and DnaJ3 were suggested to be involved in the biogenesis and/or maintenance of TMs [16,25,31]. The DnaK3s of both Synechococcus and Synechocystis co-purify with membranes, and the unique DnaK3 C-terminus has been implicated to mediate tight membrane binding of DnaK3 in Synechocystis [15,31]. However, what might be the function of DnaK3 at TMs?

The function of a cyanobacterial DnaK3 has recently been linked to the PS II reaction center protein D1 [16], the main target of stress-induced damage in the photosynthetic electron transport chain, which is constantly degraded and replaced by newly synthesized proteins in a PS II repair cycle [32,33]. Furthermore, a Hsp70 chaperone is involved in the biogenesis, protection and/or repair of PS II complexes in chloroplasts [34,35]. Based on these observations we hypothesized that the physiological functions of DnaK proteins might have diverged in cyanobacteria, and DnaK3 potentially is specifically involved in biosynthesis/maintenance of TM complexes involved in photosynthesis.

In the present study, we have analyzed the role of the Hsp70 protein DnaK3 in TM maintenance in the cyanobacterium Synechocystis sp. PCC 6803. Expression of DnaK3 is light-regulated. Reduction of the cellular DnaK3 content resulted in decreased PS and phycobilisome (PBS) contents, a lowered PS I-to-PS II ratio, a generally reduced photosynthetic activity as well as disturbed PS II activity at elevated light conditions. The observation that the PS II activity is affected after photoinhibition in a mutant strain, where the cellular DnaK3 content is reduced, and the comparison of the mutant strain with Synechocystis wt suggests a specific function of DnaK3 in PS II protection and/or repair. However, based on the here presented data its activity must be wider. Thus, our findings support the assumption that DnaK3 is involved in biogenesis and/or maintenance of TM-localized electron transfer complexes in cyanobacteria. 


\section{Materials and Methods}

\subsection{Growth Conditions}

A glucose-tolerant Synechocystis sp. PCC 6803 wild type (wt) and the merodiploid dnaK3 (sll1932) knock-down (KD) strain [15] were cultivated photomixotrophically at $30^{\circ} \mathrm{C}$ in liquid BG11 medium [36] supplemented with $5 \mathrm{mM}$ glucose. Kanamycin $(80 \mu \mathrm{g} / \mathrm{mL})$ was added in case of the dnaK3KD strain. The cultures were aerated with air enriched with $2 \% \mathrm{CO}_{2}$ and grown under fluorescent white light at a light intensity of 20 (LL, low light) or 120 (HL, high light) $\mu \mathrm{mol} / \mathrm{m}^{2} \mathrm{~s}$, respectively. To determine growth rates, the strains were initially adjusted to an $\mathrm{OD}_{750}$ of 0.05 in BG11 medium, containing $5 \mathrm{mM}$ glucose, and growth was followed by monitoring $\mathrm{OD}_{750}$. For LAHG cultures, Synechocystis cells were grown in a dark cabinet for at least two weeks, during which the cultures were diluted at least five times in fresh medium, as described previously (Barthel et al., 2013).

\subsection{SDS-PAGE and Immunoblot Analysis}

Synechocystis cells were harvested in the exponential growth phase at an $\mathrm{OD}_{750}$ below 2.0. Cell pellets were resuspended in buffer (50 mM HEPES, pH 7.0, $25 \mathrm{mM} \mathrm{CaCl}_{2}, 5 \mathrm{mM} \mathrm{MgCl} 2,10 \%(\mathrm{v} / \mathrm{v})$ glycerol) and a proteinase inhibitor mix (Sigma Aldrich) was added at a 1:1000 dilution. Cells were broken with glass beads $(0.25-0.5 \mathrm{~mm}$ diameter) in a beadbeater. Unbroken cells and glass beads were removed by centrifugation at $1600 \mathrm{~g}$ and the respective protein concentrations were determined by three independent Bradford assays. After addition of SDS sample buffer and heating at $65{ }^{\circ} \mathrm{C}$ for $15 \mathrm{~min}$, cell extracts were loaded on an $8 \%$ polyacrylamide gel and proteins were separated by SDS gel electrophoresis. Subsequently, proteins were transferred to a polyvinylidene difluoride membrane, using a wet electroblotting system from Bio-Rad. The rabbit primary antibodies were used at 1:2000 (anti-L23 directed against the large ribosomal subunit protein L23 encoded by sll1801, Gramsch laboratories, Schwabhausen, Germany), 1:1000 (anti-DnaK1, anti-DnaK2 and anti-DnaK3 [15], anti-PsaA/PsaB [37]) or 1:100 (anti-PsbA [38]) dilutions, respectively, whereas the goat anti-rabbit secondary antibody (Sigma Aldrich) was diluted 1:10,000. PsbA/D1-HRP antibodies were obtained from Agrisera and used in 1:15,000 dilution. To visualize the protein bands, membranes were incubated with the enhanced chemiluminescence kit from Pierce. Each immunoblot analysis has been repeated at least three times.

\subsection{Complete Deletion of DnaK3 in Synechocystis Cells Grown under LAHG Conditions}

To test whether DnaK3 is dispensable in the dark, the dnaK3KD strain [15] was cultivated in liquid BG11 medium under LAHG conditions and diluted if necessary. During each dilution step, the concentration of kanamycin was enhanced in the growth medium from 80 to $275 \mu \mathrm{g} \mathrm{mL}{ }^{-1}$. To check whether the strain was completely segregated, genomic DNA was isolated and analyzed by PCR using the primers NtdnaK3check (5'-gtttttagaagcggagaaagtgg-3') and CtdnaK3check (5'-cctttgggttggaaaccattgg-3').

\subsection{Cell Number and Chlorophyll Concentration Determination}

Cell numbers were counted with a light microscope using a Thoma counting chamber. Chlorophyll concentrations were determined photometrically after methanol extraction [39].

\subsection{Electron Microscopy}

To study the cell morphology of the different Synechocystis strains, cell pellets obtained from a $10 \mathrm{~mL}$ cell suspension were washed and resuspended in buffer (50 mM KH $2 \mathrm{PO}_{4}, \mathrm{pH}$ 7). Ultrastructural investigations were performed as described previously [37]. The number of thylakoid layers per cell was determined, evaluating more than 200 individual cells of wt and the DnaK3 depleted Synechocystis strain, respectively. 


\subsection{Absorbance and Low Temperature (77K) Fluorescence Spectra}

Absorbance spectra of whole cells were recorded using a Perkin-Elmer Lambda 25 spectrophotometer equipped with an integrating sphere. Cell suspensions were adjusted to a constant value of 300,000 cells $\mathrm{mL}^{-1}$. Ratios of cyanobacterial chromophores were determined using the absorption ratio at 625/680 (phycocyanin/chlorophyll) or at 490/440 (carotenoids/chlorophyll).

Low-temperature (77 K) fluorescence emission spectra were recorded using an Aminco Bowman Series 2 spectrofluorimeter. Cultures were adjusted to a chlorophyll concentration of $3 \mu \mathrm{g} \cdot \mathrm{mL}^{-1}$ in BG11 medium and frozen in liquid nitrogen. Chlorophylls were excited at $435 \mathrm{~nm}$ and phycobilisomes (PBs) at $580 \mathrm{~nm}$. Fluorescence emission was recorded from 630 to $760 \mathrm{~nm}$.

\subsection{Oxygen Evolution}

Oxygen production of the cell suspensions was determined in the presence of $500 \mu \mathrm{M}$ phenyl-p-benzoquinone (PPBQ) using a fiber-optic oxygen meter (PreSens) under actinic light (600 $\mu \mathrm{mol}$ photons $\left.\mathrm{m}^{-2} \cdot \mathrm{s}^{-1}\right)$. Prior to the measurement, the cultures were adjusted to a chlorophyll concentration of $3 \mu \mathrm{g} \cdot \mathrm{mL}^{-1}$ in BG11 medium. For experiments in presence of a protein synthesis inhibitor, $100 \mu \mathrm{g} \cdot \mathrm{mL}^{-1}$ lincomycin was added prior to illumination $\left(1500 \mu \mathrm{mol}\right.$ photons $\left.\mathrm{m}^{-2} \cdot \mathrm{s}^{-1}\right)$.

\subsection{Chlorophyll Fluorescence Induction Curves}

Cultures were adjusted to a chlorophyll concentration of $3 \mu \mathrm{g} \cdot \mathrm{mL}^{-1}$ in BG11 medium, and subsequently fluorescence induction curves were recorded at room temperature, using a Dual-PAM-100 measuring system equipped with Dual-E and DUAL-DR modules (Heinz Walz $\mathrm{GmbH})$. During the initial dark phase, background fluorescence was probed by weak measuring light $\left(0.024 \mu \mathrm{mol}\right.$ photons $\left.\mathrm{m}^{-2} \cdot \mathrm{s}^{-1}\right)$ and after $40 \mathrm{~s}$ fluorescence was induced by switching on red actinic light $\left(95 \mu \mathrm{mol}\right.$ photons $\left.\mathrm{m}^{-2} \cdot \mathrm{s}^{-1}\right)$. Saturating pulses $\left(600 \mathrm{~ms}, 10.000 \mu \mathrm{mol}\right.$ photons $\left.\mathrm{m}^{-2} \cdot \mathrm{s}^{-1}\right)$ were applied once during the dark phase and at $30 \mathrm{~s}$ intervals during the light phase, to obtain minimal $\left(\mathrm{F}_{0}\right)$ and maximal $\left(F_{m}\right.$ and $\left.F_{m^{\prime}}\right)$ fluorescence values $[40,41]$. The coefficient of photochemical quenching of the PS II Chl fluorescence (qP) was calculated using the software routine for light induction measurements $\left(\mathrm{qP}=\left(\mathrm{Fm}-\mathrm{Fm}^{\prime}\right) /\left(\mathrm{Fm}-\mathrm{Fo}^{\prime}\right)\right)$ after $250 \mathrm{~s}$ illumination with red actinic light.

\section{9. $P_{700}$ Re-Reduction Kinetics}

Re-reduction kinetics were recorded using a Dual-PAM-100 measuring system. $\mathrm{P}_{700}$ was first reduced by $10 \mathrm{sec}$ far-red and then oxidized by a $20 \mathrm{~ms}$ saturation light pulse $(10.000 \mu \mathrm{mol}$ photons $\left.\mathrm{m}^{-2} \cdot \mathrm{s}^{-1}\right) .15$ individual re-reduction curves were recorded, averaged, and fitted with single exponential functions to determine decay halftimes $\left(t_{1 / 2}\right)$. Prior to the measurement, the different cultures were adjusted to a chlorophyll concentration of $3 \mu \mathrm{g} \cdot \mathrm{mL}^{-1}$ in BG11 medium.

\section{Results}

\subsection{DnaK3 Synthesis is Light-Induced and Essential in the Dark}

The Synechocystis dnaK2 and dnaK3 genes are essential in the light [15], and the DnaK1-3 proteins were detected by Western blot analyses in Synechocystis cells grown under constant illumination [15]. However, when Synechocystis cells were grown in the dark under LAHG conditions, the DnaK2 protein, but not DnaK1 and DnaK3, were detectable (Figure 1, 0 h). Yet, when dark-adapted cells were shifted into the light, the DnaK2 level did not substantially alter, whereas the DnaK1 level quickly increased until two hours after shifting the cells into the light. DnaK3 was detectable already after one hour, and its cellular content increased steadily. Thus, the synthesis of DnaK1 and DnaK3 clearly is triggered by light in Synechocystis. 


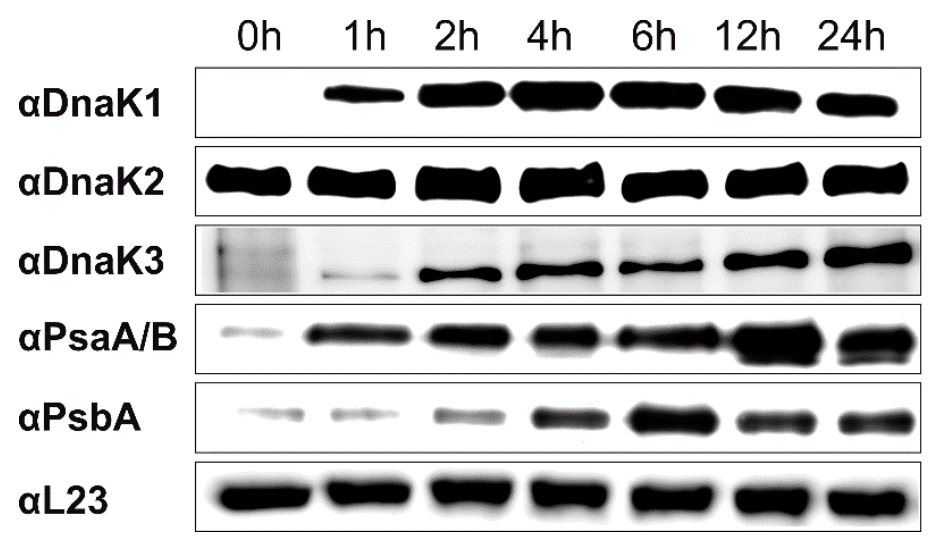

Figure 1. Light-dependent accumulation of DnaK1, 2, and 3. Dark-adapted Synechocystis cultures were shifted into the light $(0-24 \mathrm{~h})$. Cell extracts $(20 \mu \mathrm{g}$ protein) were analyzed at different time points via immunodetection, using anti-DnaK1, 2, or 3 antibodies as well as antibodies directed against PS I (PsaA/B) and PS II (PsbA) core subunits or the ribosomal protein L23 (loading control).

Since DnaK1 is not essential for the viability of Synechocystis cells [15], we focused our subsequent analyses on DnaK3.

As DnaK3 is essential in the light [15], the observation of a light-induced DnaK3 synthesis indicated that DnaK3 might be dispensable in the dark. Therefore, we next attempted to completely delete the Synechocystis dnaK3 gene in cells grown in the dark under LAHG conditions. Yet, even after more than half a year of cultivation under LAHG conditions and increasing the kanamycin concentration in the growth medium up to $275 \mu \mathrm{g} \cdot \mathrm{mL}^{-1}$, a fragment corresponding in size to the wild type (wt) dnaK3 gene was always detected via PCR in the dnaK3 knock-down $(K D)$ strain in addition to the dnaK3 gene disrupted by the kanamycin resistance ( $a p h A)$ cassette (Figure 2A,B). As Synechocystis contains multiple identical genome copies, this result indicates that some, but not all, of the genomic dnaK3 copies were deleted in the mutant strain. Thus, DnaK3 likely is essential not only in the light but also in the dark under LAHG conditions.

Yet, we recently showed that expression of $d n a J 3$ [25], which is organized in a gene cluster together with dnaK3, is essential in Synechocystis, and thus deletion of $d n a K 3$ might have affected the expression of $d n a J 3$. To assess this potential polar effect, we also quantified the amount of the DnaJ3 protein in the dnaK3KD strain (Figure 2A). Since the DnaJ3 level was not decreased compared to the wt, we concluded that insertion of the $a p h A$ cassette into the $d n a K 3$ gene locus did not dramatically affect the expression of $d n a J 3$. Nevertheless, a polar effect on expression of $d n a J 3$ cannot be completely excluded.

To quantify the relative cellular DnaK3 content in the dnaK3KD strain, total cellular extracts of the wt and the KD strain were analyzed via Western blots (Figure 2C). The intensity of each band was quantified using the Image J software and divided by the quantity of cellular extract loaded. Based on this analysis, the DnaK3 content was decreased by about $60 \% \pm 10 \%$ in the dnaK3KD strain compared to the wt. 
A
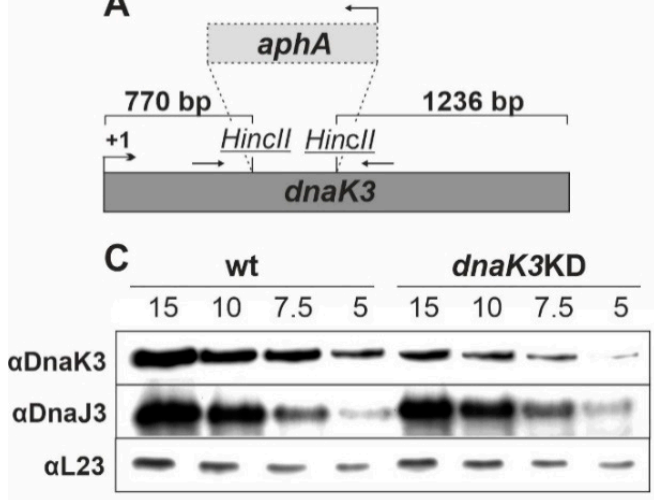

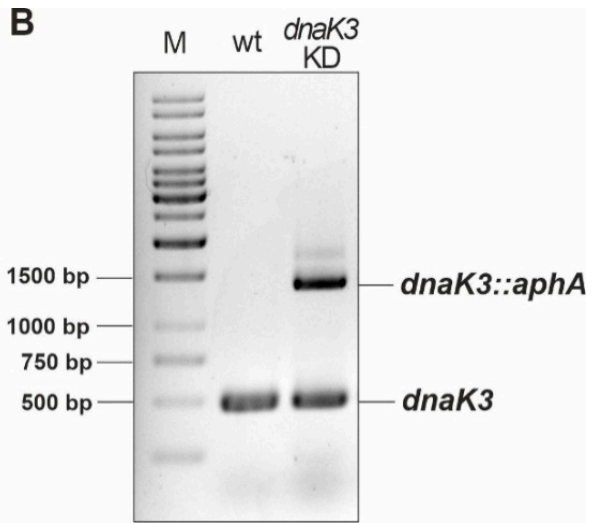

Figure 2. Deletion of dnaK3 in the dark and the DnaK3 content in the Synechocystis dnaK3KD strain. (A) In the Synechocystis dnaK3KD strain [15], the dnaK3 gene was disrupted by insertion of a kanamycin resistance cassette (aphA gene). (B) The $d n a K 3$ gene locus of wt and dnaK3KD cells grown in the dark was analyzed via PCR using genomic DNA as a template, and the PCR products were loaded on a $1.5 \%$ agarose gel together with a molecular size marker (M). Fragments of about 500 bp and $1500 \mathrm{bp}$ represent the wt and the $d n a K 3$ gene interrupted by a kanamycin resistance cassette $(a p h A)$, respectively. (C) The relative DnaK3 content in the dnaK3KD strain was determined by immunoblot analysis. Cell extracts prepared from the wt and $d n a K 3 \mathrm{KD}$ strains, respectively, were loaded on a SDS-polyacrylamide gel in descending protein concentrations ( $15 \mu \mathrm{g}$ to $5 \mu \mathrm{g})$ followed by a Western blot analysis using $\alpha$-DnaK3, $\alpha$-DnaJ3 and $\alpha$-L23 (loading control) antibodies.

\subsection{Reducing the DnaK3 Content Affects Cell Growth under Heat Stress Conditions}

Next, we tested whether reducing the DnaK3 content affects growth of the mutant strain under low (LL) or high light (HL) growth conditions, respectively (Figure 3A). The dnaK3KD and the wt cells had comparable doubling times of $11.2 \mathrm{~h} \pm 0.1(\mathrm{wt})$ and $11.1 \mathrm{~h} \pm 0.2($ dnaK3KD), and of $8.1 \mathrm{~h} \pm 0.5(\mathrm{wt})$ and $9.4 \pm 1.2$ (dnaK3KD) under LL and HL growth conditions, respectively. Thus, reducing the cellular DnaK3 content does not severely affect the growth of Synechocystis cells, at least not under standard laboratory growth conditions. Subsequently, growth of the dnaK3KD strain was tested under various stress conditions (involving low $\mathrm{pH}$, low temperature, oxidative and osmotic stress; data not shown), but solely increasing the temperature to $42{ }^{\circ} \mathrm{C}$ resulted in an obvious growth defect of the mutant strain, with doubling times of $26.4 \pm 3.5 \mathrm{~h}(\mathrm{dnaK3KD})$ and $17.9 \pm 0.4 \mathrm{~h}(\mathrm{wt})$ (Figure 3B). This observation classifies DnaK3 as a traditional Hsp70 involved in heat-stress responses.

A

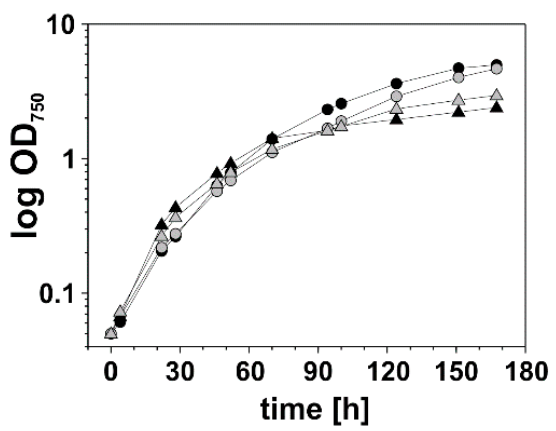

B

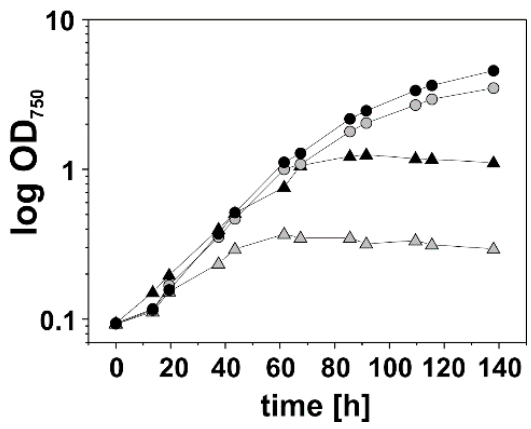

Figure 3. Growth of Synechocystis wt and the dnaK3KD mutant strain at different growth conditions. Synechocystis wt (black) and dnaK3KD mutant (gray) cells were grown at (A) moderate temperature $\left(30^{\circ} \mathrm{C}\right)$ or $(\mathbf{B})$ elevated temperature $\left(42^{\circ} \mathrm{C}\right)$ under low light (circle) or high light (triangle) conditions. Cells were adjusted to $\mathrm{OD}_{750}=0.05$ in BG11 medium containing $5 \mathrm{mM}$ glucose and cell growth was followed over time by measuring the $\mathrm{OD}_{750}$. 


\subsection{The dnaK3KD Strain Has a Reduced Pigment Content}

Photosynthesis is one of the most temperature-sensitive processes in phototrophic organisms and the photosynthetic activity is further impaired when heat-stress is combined with HL [42,43]. Thus, it was well possible that reducing the DnaK3 content affects photosynthetic processes in Synechocystis.

As expression of dnaK3 is light-controlled (Figure 1), we subsequently analyzed the pigment content of the wt and dnaK3KD strains after cultivation under LL and HL conditions, respectively. Adaptation of Synechocystis cells to HL conditions is typically accompanied by a reduction in the cellular amount of the two PSs, a decreased PS I-to-PS II ratio and a reduced chlorophyll (Chl) content per cell [44,45].

An overall reduction of the pigment content was observed under HL growth conditions when equal amounts of cells were analyzed (Figure 4A). The Chl content was reduced to about half (Figure 4B) and the relative content of plastocyanine (PC) (Figure 4C) and carotenoids (Car) (Figure 4D) were both increased. It has to be noted that while the contents of Chl, PC and Car were decreased under HL growth conditions (Figure 4A), the $\mathrm{PC} / \mathrm{Chl}$ as well as the $\mathrm{Car} / \mathrm{Chl}$ ratios were increased in the wt strain, due to the more severely decreased Chl content (Figure 4A,B). Even though light scattering could have contributed to some extent to the determined (absolute) absorbance values used in these analyses, these data clearly show the ability of the wt to reduce the overall pigment content and to adapt it to HL conditions.
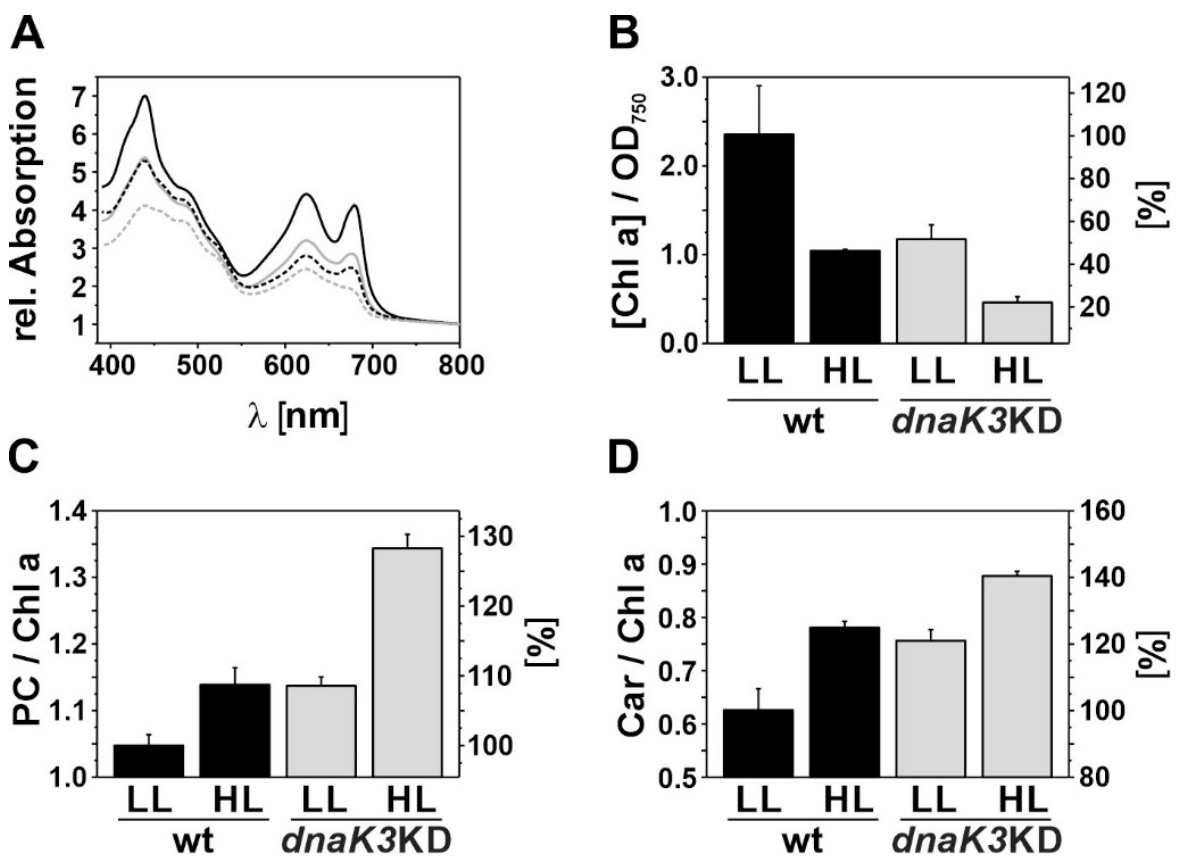

Figure 4. Pigment content and pigment ratios. (A) Absorbance spectra of Synechocystis wt (black) and dnaK3KD (gray) cells (300,000 cells) grown under LL (solid line) or HL (dashed line) conditions. (B) The chlorophyll content per $\mathrm{OD}_{750}$ was determined as described in "Material and Methods".

(C) The ratio of PC to Chl was determined as the ratio of the absorptions at 625 and $680 \mathrm{~nm}$.

(D) The ratio of Car to $\mathrm{Chl}$ was determined as the ratio of the absorption at 490 and $440 \mathrm{~nm}$. Error bars represent standard deviation from three independent experiments.

Similarly, the $d n a K 3 K D$ strain adapted to changing light conditions and reduced its pigment content as expected when grown under HL conditions. However, the dnaK3KD strain exhibited a severely reduced pigment content already when grown under LL conditions, and the Chl content as well as the pigment ratios were very similar to the ones observed when the wt was grown under HL conditions (Figure 4). 
Besides the obvious differences in pigmentation, the TM structure was mostly unaffected, and we only observed a slightly reduced number of TM pairs in the mutant strain when the ultrastructure of Synechocystis grown under LL growth conditions was analyzed via electron microscopy (Figure 5).

A

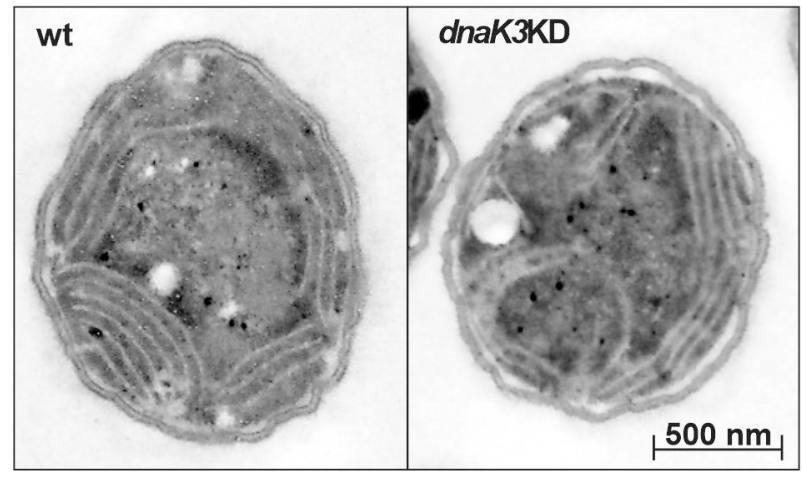

B

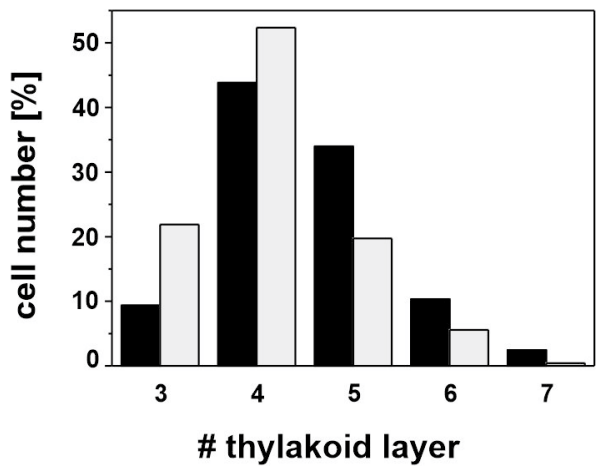

Figure 5. Reducing the cellular DnaK3 content results in fewer thylakoid layers. (A) Representative electron micrographs of Synechocystis wt and dnaK3KD mutant cells cultivated under LL (low light) conditions. (B) Cells of the dnaK3KD mutant strain (gray) had four thylakoid layers on average, whereas wt cells (black) showed four to five layers and a higher appearance of six and seven layers of TM pairs. Per strain, at least 200 individual cells were counted.

\subsection{Reducing the DnaK3 Content Results in an Altered PS I-to-PS II Ratio}

Next, the relative amounts of PS II and PS I in the DnaK3 reduced strain were determined via $77 \mathrm{~K}$ fluorescence spectroscopy (Figure 6A). Upon chlorophyll excitation at $435 \mathrm{~nm}$, characteristic fluorescence emission maxima were detected at $721 \mathrm{~nm}$ (PS I), at $684 \mathrm{~nm}$ (CP43, PS II) and $693 \mathrm{~nm}$ (CP47, PS II).

Synechocystis wt cells grown under HL conditions showed a decreased PS I-to-PS II ratio compared to LL-adapted cells (Figure 6A), which is a well-documented long-term adaptation to HL [44,46,47]. In contrast, $d n a K 3 \mathrm{KD}$ cells had a considerably decreased PS I-to-PS II ratio already under LL growth conditions. This finding is also supported by a Western blot analysis. When an identical quantity of protein was loaded, the Western blot shows that PS core subunits PsaA/B (PS I) and PsbA (PS II) are less abundant in the dnak3KD strain (Figure 6C). When the cell extracts were normalized based on the Chl concentration (Figure 6D), no difference in the band intensity was observed in case of PsaA/B, since in Synechocystis about $85 \%$ of the Chl is bound to PS I (assuming a PS I/PS II ratio of 2.5 [48], 96 chlorophylls per PS I [49], and $35 \mathrm{chl}$ per PS II [50]). However, the PsbA band was more pronounced in the mutant strain when compared to the wt, which further supports the decreased PS I-to-PS II ratio in this strain. The decreased PS I-to-PS II ratio decreases even further when cells were shifted into HL (Figure 6A).

However, at LL as well as at HL conditions, an increased relative fluorescence emission was observed at $684 \mathrm{~nm}\left(\lambda_{\mathrm{ex}}=435 \mathrm{~nm}\right)$ in the mutant strain (Figure 6A). This fluorescence emission maximum originates from PS II as well as from the PBSs terminal emitter LCM [51], and thus indicates an increased relative phycobiliprotein content, as already observed in the absorbance measurements (Figure 4A,C). Yet, the increased PBSs fluorescence emission at $684 \mathrm{~nm}$ is solely observed when PBSs are uncoupled and do not transfer the harvested light energy to the PSs [51,52]. Thus, to next assess energy transfer from PBSs to PS II, phycobiliproteins were excited at $580 \mathrm{~nm}$ and energy transfer to PS II was followed. When PBSs are coupled to PS II, light energy harvested by the PBS is transferred to PS II, resulting in quenching of the PBS fluorescence [53,54]. As can be seen in Figure 6B, upon PBS excitation an increased fluorescence emission at $684 \mathrm{~nm}$ (PBSs plus PS II) was observed but not at $693 \mathrm{~nm}$ (PS II) (Figure 6B). Thus, the dnaK3KD strain indeed contains an increased amount of uncoupled PBSs compared to the wt. 
The decreased fluorescence emission at $721 \mathrm{~nm}$ results from the decreased PS I content (Figure 6A) and most likely not from light-dependent energy distribution via state transitions, which is supposed to be physiologically important solely under LL growth conditions [55,56].
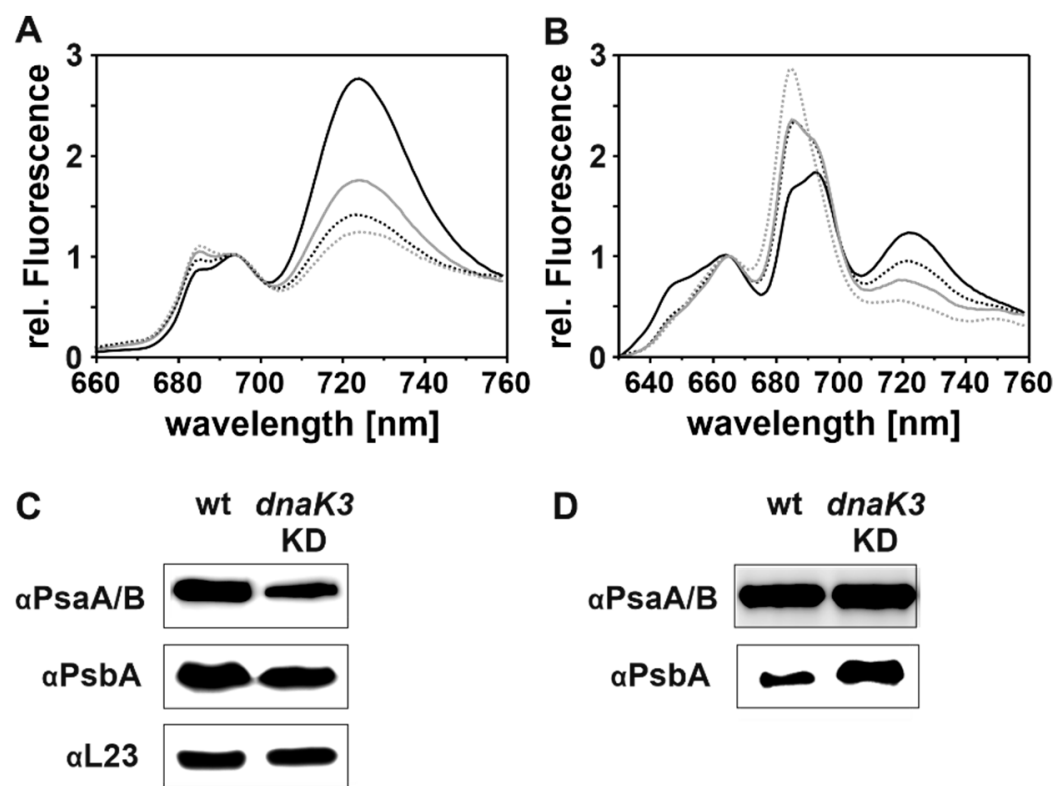

Figure 6. Reduction of the cellular DnaK3 content results in a decreased PS content and a lowered PS I-to-PS II ratio. (A) $77 \mathrm{~K}$ fluorescence emission spectra of wt (black) and dnaK3KD (gray) cultures grown under LL (solid line) and HL (high light) (dashed line) conditions. The spectra were normalized at $695 \mathrm{~nm}$. $\lambda_{\mathrm{Ex}}=435 \mathrm{~nm}$ (B) $77 \mathrm{~K}$ fluorescence emission spectra of wt (black) and dnaK3KD (gray) cultures cultivated under LL (solid line) and HL (dashed line) conditions. The spectra were normalized at $665 \mathrm{~nm}$. $\lambda_{\mathrm{Ex}}=580 \mathrm{~nm}$. (C,D) Immunoblot analysis of the content of PS I and PS II core subunits (PS I: PsaA/B; PS II: PsbA) in wt and dnaK3KD cells grown under LL conditions. Samples were normalized to (C) protein $(25 \mu \mathrm{g})$ or $(\mathrm{D})$ chlorophyll $(0.6 \mu \mathrm{g})$. L23 is the loading control.

Taken together, the fluorescence spectra and the Western blot analyses reveal that the mutant has a generally decreased PS content, with a decreased PS I-to-PS II ratio and an increased amount of uncoupled phycobiliproteins. However, the mutant strain still adjusts the PS I-to-PS II ratio to changing light conditions, as observed for the wt strain.

\subsection{The Photosynthetic Activity is Impaired in the DnaK3 Depleted Strain}

Next, the photosynthetic activity of the mutant strain with a reduced DnaK3 content was studied in greater detail. By measuring oxygen evolution rates in presence of PPBQ, the activity of PS II can be specifically determined (Figure 7A,B). When adapted to $\mathrm{HL}$ growth conditions, the $\mathrm{O}_{2}$ evolution rate per cell $\left(\mathrm{OD}_{750}\right)$ was reduced in the wt strain compared to LL growth conditions (Figure 7A), in line with the observation that the light-harvesting capacity is generally reduced in cyanobacterial cells under HL conditions [57]. In contrast to wt cells, the dnaK3KD strain showed a dramatically decreased $\mathrm{O}_{2}$ evolution rate already under LL conditions, when compared to the wt, and the activity decreased even further under HL conditions (Figure 7A). However, when the $\mathrm{O}_{2}$ evolution rates were normalized to the $\mathrm{Chl}$ content, the $\mathrm{O}_{2}$ evolution rate remained essentially stable in the wt, regardless of the light conditions (Figure 7B). In contrast, the $\mathrm{O}_{2}$ evolution rate was only marginally lower for the mutant strain under LL growth conditions than for the wt, but dramatically decreased under HL growth conditions. Thus, in contrast to the wt, the decreased $\mathrm{O}_{2}$ evolution in the mutant strain is not only a consequence of the decreased cellular Chl content (Figure 4B), since the $\mathrm{O}_{2}$ evolution rate was also drastically decreased when the measurements were normalized to the Chl content (Figure 7B). 
A

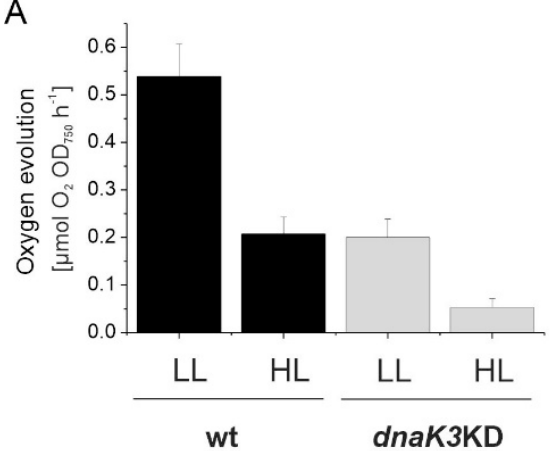

C

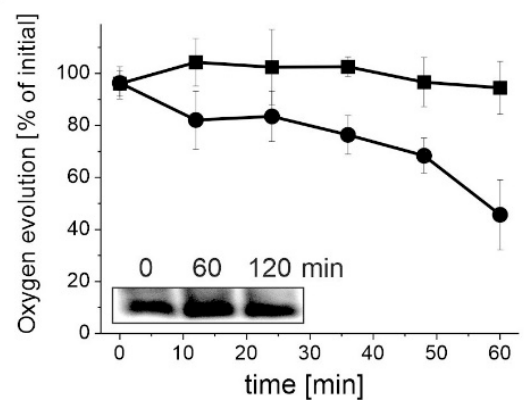

B

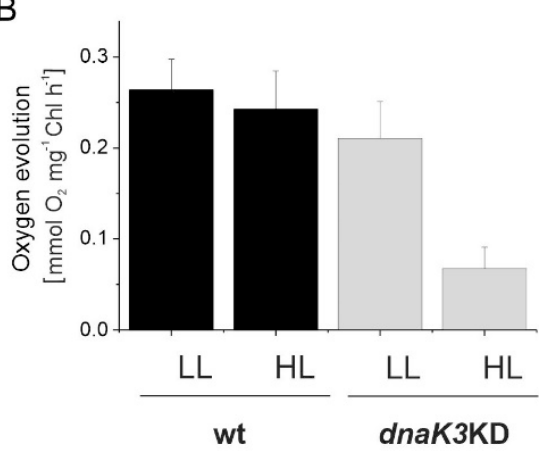

$\mathrm{D}$

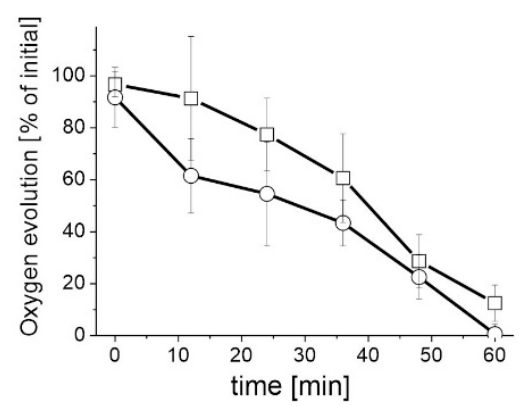

Figure 7. Oxygen evolution rates and relative PS II content of wt and dnaK3KD Synechocystis cells. $(\mathbf{A}, \mathbf{B}) \mathrm{wt}$ and dnaK3KD cells were grown under LL and HL conditions, respectively, and oxygen evolution rates were determined per $\mathrm{OD}_{750}(\mathbf{A})$ or $\mathrm{Chl}(\mathbf{B})$. (C,D) wt (square) and dnaK3KD (circle) cells were exposed to extreme high light (eHL) conditions $\left(1500 \mu \mathrm{mol}\right.$ photons $\left.\mathrm{m}^{-2} \cdot \mathrm{s}^{-1}\right)$ either in absence (C) or presence (D) of lincomycin $\left(100 \mu \mathrm{g} \cdot \mathrm{mL}^{-1}\right)$ and thereafter cultured under LL conditions for recovery. Oxygen evolution was measured using $500 \mu \mathrm{M}$ phenyl-p-benzoquinone (PPBQ) as an electron acceptor at PS II. The recovery rate is given by the slope of a linear regression under LL conditions. Noteworthy, no other antibiotics were present in these experiments. Inlet in (C): Immunoblot analysis of the D1 content in the dnaK3KD strain after photoinhibition (time 0). Cell extracts with identical Chl contents $(0.4 \mu \mathrm{g})$ were analyzed. (Error bars represent standard deviation from three independent experiments).

To test whether reducing the DnaK3 content somehow impairs PS II repair, we next determined $\mathrm{O}_{2}$ evolution rates under extreme HL conditions $\left(1500 \mu \mathrm{mol}\right.$ photons $\left.\mathrm{m}^{-2} \cdot \mathrm{s}^{-1}\right)$ in presence or absence of lincomycin, a protein synthesis inhibitor that has already been successfully used to block the PS II repair cycle in Synechocystis [58,59]. In absence of lincomycin, the wt strain did not show any changes in the PS II activity under constant extreme HL illumination, i.e., the wt cells harbor an effective PS II repair cycle (Figure 7C). However, in presence of lincomycin, the PS II activity constantly decreased when cells were illuminated with extreme HL (Figure 7D). The decreasing PS II activity, i.e., an impaired PS II protection and/or repair, can be observed for both the wt and the dnaK3KD strain in presence of lincomycin (Figure 7D). However, in absence of lincomycin, the PS II activity was already lower in the $d n a K 3 \mathrm{KD}$ than in the wt strain after 10 min of illumination and constantly decreased further to about $50 \%$ after $1 \mathrm{~h}$ of illumination, whereas the wt activity remained about constant (Figure 7C).

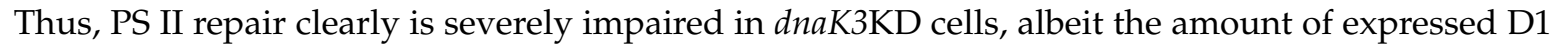
protein did not alter (inlet in Figure 7C). Thus, PS II protection and/or repair is affected especially under light-stress conditions.

The photochemical efficiency of PS II can be specifically assessed using pulse amplitude modulated (PAM) fluorescence measurements. Therefore, dark/light induction curves were recorded (Figure 8A). A minimal fluorescence $\left(\mathrm{F}_{0}\right)$ is visible due to the measuring light, which, however, is not strong enough to stimulate photosynthetic electron transfer. Subsequently, a pulse of intense white light is given to reduce all PS II reaction centers, resulting in maximal fluorescence $\left(F_{m}\right)$. The parameter $F_{v} / F_{m}$ $\left(F_{v}=F_{m}-F_{o}\right)$ is used to describe the maximal photochemical efficiency (Figure 8B) [60]. 
A

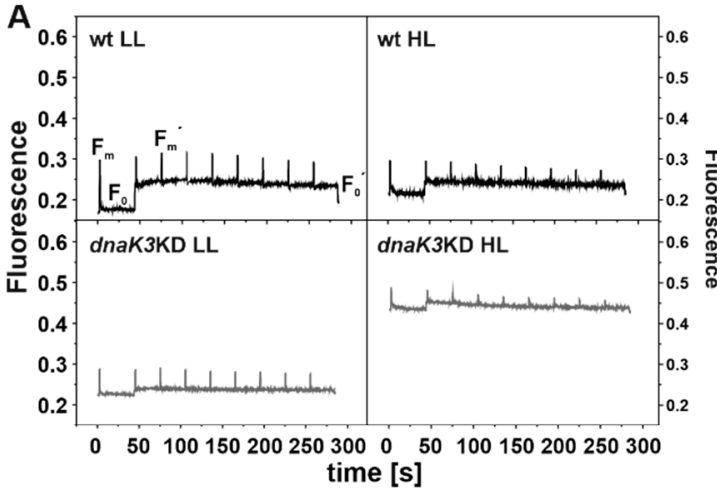

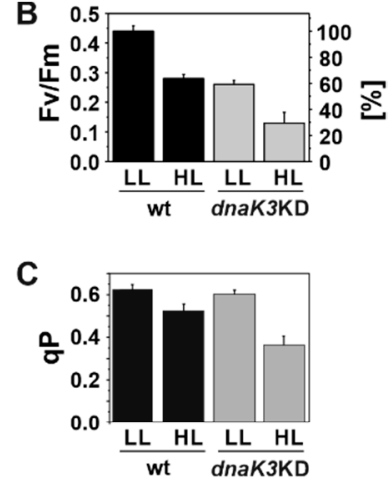
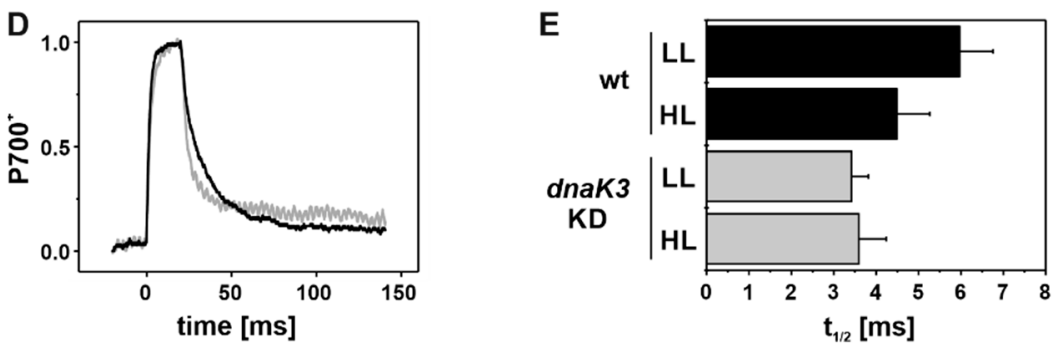

Figure 8. PS II activity and $\mathrm{P}_{700}$ re-reduction kinetics. (A) Light/dark induction curves were recorded by measuring the pulse amplitude modulated (PAM) fluorescence of wt (black) and dnaK3KD cells (gray) grown under LL or HL conditions, respectively. After $40 \mathrm{~s}$ of measuring light, the actinic red light was switched on to determine minimal fluorescence values $\left(\mathrm{F}_{0}, \mathrm{~F}_{0}{ }^{\prime}\right)$. Pulses of saturating light were applied once during the dark phase and in $30 \mathrm{~s}$ intervals during the light phase, to obtain maximal $\left(F_{m}\right.$ and $\left.F_{m}{ }^{\prime}\right)$ fluorescence values. (B) Maximal PS II photosynthetic activity of the wt (black) and the dnaK3KD strain (gray). (C) The coefficient of photochemical quenching of PS II Chl fluorescence (qP) in wt (black) and dnaK3KD cells (gray). (B, C) Error bars represent standard deviation from at least four independent experiments. (D) $\mathrm{P}_{700}{ }^{+}$re-reduction kinetics of wt (black) and dnaK3KD (gray) cells grown under LL conditions. A saturation pulse of $10,000 \mu \mathrm{mol}$ photons was given for $20 \mathrm{~ms}$ to completely oxidize $\mathrm{P}_{700}$. The following fluorescence decrease illustrates re-reduction of $\mathrm{P}_{700}{ }^{+}$in the dark. At least ten traces were averaged and normalized. 1 represents completely oxidized and 0 completely reduced $P_{700}$. (E) Re-reduction halftimes were determined via fitting the decay curves of the wt (black) and the dnaK3KD mutant strain (gray) with single exponential functions. Error bars represent standard deviation from at least three independent experiments.

After switching on actinic light, an increased background fluorescence was detected, and PS II centers became photosynthetically active (Figure 8A). Saturating light pulses resulted in a lowered $\mathrm{F}_{\mathrm{m}}$ ' compared to the maximal fluorescence $\mathrm{F}_{\mathrm{m}}$ measured in the dark, due to non-photochemical quenching processes [61]. An apparent increase of the absolute $F_{0}$ background fluorescence was measured for wt cells grown under HL conditions compared to LL and for the dnaK3KD cells (grown under either condition), indicating a more reduced plastoquinone (PQ) pool (Figure $8 \mathrm{~A}$ ). However, determining $\mathrm{F}_{0}$ and $\mathrm{F}_{0}{ }^{\prime}$ is somewhat problematic in cyanobacteria, as the PBS fluorescence can in part also contribute to the determined $\mathrm{F}_{0}$ fluorescence value [62], and thus discussion of solely $\mathrm{F}_{0}$ values is difficult. Hence, we also present the normalized coefficient of photochemical quenching of PS II Chl fluorescence (qP), which is not significantly biased by PBSs fluorescence [63]. qP is defined as 1 in the dark-adapted state and may decrease to 0 when all PS II centers are closed. In line with Figure 7B, in the wt strain slightly less PS II centers are open under HL conditions compared to LL. In the mutant strain, qP is similar to the wt under LL conditions, yet the value was dramatically decreased when dnaK3KD cells were grown under HL conditions, indicating an increased amount of closed PS II centers. Thus, the dnaK3KD strain can hardly cope with high light treatment. This observation is in excellent agreement with the determined $\mathrm{O}_{2}$ evolution rates (Figure 7), showing an impaired PS II protection and/or repair cycle. 
$\mathrm{P}_{700}{ }^{+}$re-reduction measurements allow determining the time needed to re-reduce the oxidized PS I reaction center $\mathrm{P}_{700}{ }^{+}$, which is not only affected by the PS I activity but also by the redox state of the electron transport chain (Figure $8 \mathrm{D}, \mathrm{E}$ ). The $\mathrm{P}_{700}{ }^{+}$absorbance signal increased when a saturating light pulse, which completely oxidized $\mathrm{P}_{700}$, was given and subsequently decreased due to $\mathrm{P}_{700}{ }^{+}$ reduction by PC (Figure 8D). The halftime of the re-reduction kinetic was determined by fitting the changes in the absorbance signal with a single exponential function (Figure 8E). A faster re-reduction rate was observed for wt cells when cells were grown under HL compared to LL conditions, which likely originates from the reduced PS I content and the decreased PS I-to-PS II ratio (Figures 6 and 8). In contrast, the dnaK3KD mutant strain had reduced re-reduction halftimes under both tested light conditions, and the halftimes were identical, regardless of the light condition (Figure 8E). The reduced re-reduction halftimes can be explained by a more reduced PQ-pool and thus nicely support the conclusions drawn from the results shown in Figures 6 and 8. Together, these results demonstrate that the activity of PS II, but not of PS I, is impaired in the dnaK3KD mutant strain.

\section{Discussion}

Three different DnaK proteins are expressed in the cyanobacterium Synechocystis sp. PCC 6803. While two of the cyanobacterial DnaK proteins, DnaK2 and DnaK3, are essential, solely DnaK2 can be classified as a canonical Hsp70 protein, expression of which can largely alter under various stress conditions $[24,64,65]$. In contrast, the DnaK3 chaperone of Synechocystis has been suggested to be specifically involved in biogenesis and/or maintenance of TMs [16,25]. However, thus far this assumption was essentially exclusively based on the observations that (i) DnaK3 is attached to TMs and (ii) DnaK3 is encoded in all cyanobacterial genomes, except in Gloeobacter violaceus, the only cyanobacterium that does not contain an internal TM system [15,29].

Albeit the cellular DnaK3 content clearly is light-regulated (Figure 1), a basal DnaK3 level appears to be required for survival of Synechocystis cells not only in the light but also under LAHG conditions (Figure 2), where cells still have rudimentary TMs. Based on the CyanoExpress database the dnaK3 transcript level does not appear to adjust to changing light conditions in Synechocystis [66] or in Synechococcus sp. PCC 7942 [16]. Thus, (light-dependent) DnaK3 synthesis likely is post-transcriptionally regulated, as common in cyanobacteria $[67,68]$.

A general decrease in the PS and PBS content per cell as well as a selective down-regulation of PS I is crucially involved in the adaptation of Synechocystis cells to HL conditions [46,67]. All these (expected) adjustments were observed when the Synechocystis wt strain was shifted from LL to HL growth conditions (Figures 6 and 7). Also, in case of the mutant strain, typical HL-adaptation processes were observed, although the light-induced changes were far less pronounced, since the mutant strain already exhibited characteristics of an HL-stressed strain under LL growth conditions. While in the dnaK3KD strain the relative PS I content was reduced and the PS I-to-PS II ratio per cell was lower than in the wt (Figure 6), PS I appears to function normally when DnaK3 was depleted, because re-reduction of PS I was even faster in the mutant strain (Figure 8E), most likely due to the more reduced PQ-pool, which also results in a significant amount of the PBSs being detached from PS II (Figure 6B).

Yet, the activity of PS II was clearly reduced in the mutant strain (Figures 7 and 8). A significant amount of PS II was inactive, potentially due to increased photodamage and/or impaired repair (Figures 7 and 8). Thus, DnaK3 likely is involved in PS II biogenesis and/or repair. In line with this assumption, expression of the Synechocystis dnaK3 gene was found being enhanced under UV-B stress [68]. Furthermore, the PS II core subunit D1 was proposed to be a substrate for DnaK3, which potentially guides the nascent polypeptide at the ribosome to the TM, where translation is completed [16]. The D1 protein is known to be especially susceptible to photodamage, and photodamaged D1 is rapidly degraded and replaced by newly synthesized protein to maintain a certain level of active PS II centers in cyanobacteria [33]. Thus, the here presented results clearly indicate that biogenesis and/or repair of PS II is impaired when the cellular DnaK3 content is reduced. 
However, the observation that DnaK3 appears to be vital also in the dark (Figure 2), where PS II is inactive [7] and the finding that D1 is not essential for survival of Synechocystis under photoheterotrophic conditions [69] indicates that DnaK3 likely has additional physiological functions beyond PS II protection and/or repair. In cyanobacteria, TMs also contain the complexes of the respiratory $\mathrm{e}^{-}$-transfer chain [70], and the indications of an over-reduced PQ pool (Figures 6 and 8) suggests that other proteins and protein complexes are also affected when the DnaK3 content is reduced. A broader implication of DnaK3 in TM biogenesis and maintenance, involving biogenesis and/or repair of multiple TM complexes would be a convincing explanation.

Author Contributions: A.T., D.S., R.J. and T.S. designed the research, A.T., R.J., T.S., and U.K. performed the experiments, A.T., D.S., and T.S. wrote the manuscript. All authors have read and agreed to the published version of the manuscript.

Funding: This research was funded by the Deutsche Forschungsgemeinschaft and a grant from the Ernst \& Margarete Wagemann Foundation.

Acknowledgments: We thank R. Genswein for excellent technical assistance and Hildegard Pearson as well as Rebecca Keller for critically reading the manuscript. We also thank M. Rögner (Ruhr-University Bochum) for the kind gift of antibodies.

Conflicts of Interest: The authors declare no conflict of interest.

\section{References}

1. Rast, A.; Heinz, S.; Nickelsen, J. Biogenesis of thylakoid membranes. Biochim. Biophys. Acta Bioenerg. 2015, 1847, 821-830. [CrossRef] [PubMed]

2. Vothknecht, U.C.; Westhoff, P. Biogenesis and origin of thylakoid membranes. Biochim. Biophys. Acta 2001, 1541, 91-101. [CrossRef]

3. Jarvis, P.; López-Juez, E. Biogenesis and homeostasis of chloroplasts and other plastids. Nat. Rev. Mol. Cell Biol. 2013, 14, 787-802. [CrossRef] [PubMed]

4. Dubreuil, C.; Jin, X.; Barajas-López, J.d.D.; Hewitt, T.C.; Tanz, S.K.; Dobrenel, T.; Schröder, W.P.; Hanson, J.; Pesquet, E.; Grönlund, A.; et al. Establishment of Photosynthesis through Chloroplast Development Is Controlled by Two Distinct Regulatory Phases. Plant Physiol. 2018, 176, 1199-1214. [CrossRef]

5. Vernotte, C.; Picaud, M.; Kirilovsky, D.; Olive, J.; Ajlani, G.; Astier, C. Changes in the Photosynthetic Apparatus in the Cyanobacterium Synechocystis sp Pcc-6714 Following Light-to-Dark and Dark-to-Light Transitions. Photosyn. Res. 1992, 32, 45-57. [CrossRef]

6. Anderson, S.L.; Mcintosh, L. Light-activated heterotrophic growth of the cyanobacterium Synechocystis sp. strain PCC 6803: A blue-light-requiring process. J. Bacteriol. 1991, 173, 2761-2767. [CrossRef]

7. Barthel, S.; Bernat, G.; Seidel, T.; Rupprecht, E.; Kahmann, U.; Schneider, D. Thylakoid Membrane Maturation and PSII Activation Are Linked in Greening Synechocystis sp PCC 6803 Cells. Plant Physiol 2013, 163, 1037-1046. [CrossRef]

8. Mechela, A.; Schwenkert, S.; Soll, J. A brief history of thylakoid biogenesis. Open Biol. 2019, 9, 180237. [CrossRef]

9. Spence, E.; Bailey, S.; Nenninger, A.; Moller, S.G.; Robinson, C. A homolog of Albino3/OxaI is essential for thylakoid biogenesis in the cyanobacterium Synechocystis sp PCC6803. J. Biol. Chem. 2004, 279, 55792-55800. [CrossRef]

10. Thurotte, A.; Brüser, T.; Mascher, T.; Schneider, D.; Brueser, T. Membrane chaperoning by members of the PspA/IM30 protein family. Commun. Integr. Biol. 2017, 10, e1264546. [CrossRef]

11. Heidrich, J.; Thurotte, A.; Schneider, D. Specific interaction of IM30/Vipp1 with cyanobacterial and chloroplast membranes results in membrane remodeling and eventually in membrane fusion. Biochim. Biophys. Acta Biomembr. 2017, 1859, 537-549. [CrossRef] [PubMed]

12. Siebenaller, C.; Junglas, B.; Schneider, D. Functional Implications of Multiple IM30 Oligomeric States. Front. Plant Sci. 2019, 10, 1500. [CrossRef] [PubMed]

13. Jilly, R.; Khan, N.Z.; Aronsson, H.; Schneider, D. Dynamin-Like Proteins Are Potentially Involved in Membrane Dynamics within Chloroplasts and Cyanobacteria. Front. Plant Sci. 2018, 9, 206. [CrossRef] [PubMed] 
14. Bryan, S.J.; Burroughs, N.J.; Evered, C.; Sacharz, J.; Nenninger, A.; Mullineaux, C.W.; Spence, E.M. Loss of the SPHF Homologue Slr1768 Leads to a Catastrophic Failure in the Maintenance of Thylakoid Membranes in Synechocystis sp PCC 6803. PLoS ONE 2011, 6, e19625. [CrossRef]

15. Rupprecht, E.; Gathmann, S.; Fuhrmann, E.; Schneider, D. Three different DnaK proteins are functionally expressed in the cyanobacterium Synechocystis sp. PCC 6803. Microbiology 2007, 153, 1828-1841. [CrossRef]

16. Katano, Y.; Nimura-Matsune, K.; Yoshikawa, H. Involvement of DnaK3, one of the three DnaK proteins of cyanobacterium Synechococcus sp PCC7942, in translational process on the surface of the thylakoid membrane. Biosci. Biotechnol. Biochem. 2006, 70, 1592-1598. [CrossRef]

17. Frick, G.; Su, Q.X.; Apel, K.; Armstrong, G.A. An Arabidopsis porB porC double mutant lacking light-dependent NADPH: protochlorophyllide oxidoreductases B and C is highly chlorophyll-deficient and developmentally arrested. Plant J. 2003, 35, 141-153. [CrossRef]

18. Hagio, M.; Sakurai, I.; Sato, S.; Kato, T.; Tabata, S.; Wada, H. Phosphatidylglycerol is essential for the development of thylakoid membranes in Arabidopsis thaliana. Plant Cell Physiol. 2002, 43, 1456-1464. [CrossRef]

19. Paddock, T.N.; Mason, M.E.; Lima, D.F.; Armstrong, G.A. Arabidopsis protochlorophyllide oxidoreductase A (PORA) restores bulk chlorophyll synthesis and normal development to a porB porC double mutant. Plant Mol. Biol. 2010, 72, 445-457. [CrossRef]

20. Sato, N.; Hagio, M.; Wada, H.; Tsuzuki, M. Requirement of phosphatidylglycerol for photosynthetic function in thylakoid membranes. Proc. Natl. Acad. Sci. USA 2000, 97, 10655-10660. [CrossRef]

21. Mayer, M.P.; Bukau, B. Hsp70 chaperones: Cellular functions and molecular mechanism. Cell. Mol. Life Sci. 2005, 62, 670-684. [CrossRef] [PubMed]

22. Genevaux, P.; Georgopoulos, C.; Kelley, W.L. The Hsp70 chaperone machines of Escherichia coli: A paradigm for the repartition of chaperone functions. Mol. Microbiol. 2007, 66, 840-857. [CrossRef] [PubMed]

23. Rajaram, H.; Chaurasia, A.K.; Apte, S.K. Cyanobacterial heat-shock response: Role and regulation of molecular chaperones. Microbiology 2014, 160, 647-658. [CrossRef] [PubMed]

24. Rupprecht, E.; Düppre, E.; Schneider, D. Similarities and Singularities of Three DnaK Proteins from the Cyanobacterium Synechocystis sp. PCC 6803. Plant Cell Physiol. 2010, 51, 1210-1218. [CrossRef]

25. Düppre, E.; Rupprecht, E.; Schneider, D. Specific and promiscuous functions of multiple DnaJ proteins in Synechocystis sp PCC 6803. Microbiology 2011, 157, 1269-1278. [CrossRef]

26. Nimura, K.; Takahashi, H.; Yoshikawa, H. Characterization of the dnaK multigene family in the cyanobacterium Synechococcus sp strain PCC7942. J. Bacteriol. 2001, 183, 1320-1328. [CrossRef]

27. Nakamoto, H.; Fujita, K.; Ohtaki, A.; Watanabe, S.; Narumi, S.; Maruyama, T.; Suenaga, E.; Misono, T.S.; Kumar, P.K.R.; Goloubinoff, P.; et al. Physical interaction between bacterial heat shock protein (Hsp) 90 and Hsp70 chaperones mediates their cooperative action to refold denatured proteins. J. Biol. Chem. 2014, 289, 6110-6119. [CrossRef]

28. Oguchi, K.; Nimura, K.; Yoshikawa, H.; Takahashi, H. Sequence and analysis of a dnaJ homologue gene in cyanobacterium Synechococcus sp. PCC7942. Biochem. Biophys. Res. Commun. 1997, 236, 461-466. [CrossRef]

29. Nakamura, Y.; Kaneko, T.; Sato, S.; Mimuro, M.; Miyashita, H.; Tsuchiya, T.; Sasamoto, S.; Watanabe, A.; Kawashima, K.; Kishida, Y.; et al. Complete genome structure of Gloeobacter violaceus PCC 7421, a cyanobacterium that lacks thylakoids. DNA Research 2003, 10, 137-145. [CrossRef]

30. Rippka, R.; Waterbury, J.; Cohenbazire, G. Cyanobacterium Which Lacks Thylakoids. Arch. Microbiol. 1974, 100, 419-436. [CrossRef]

31. Nimura, K.; Yoshikawa, H.; Takahashi, H. DnaK3, one of the three DnaK proteins of cyanobacterium Synechococcus sp. PCC7942, is quantitatively detected in the thylakoid membrane. Biochem. Biophys. Res. Commun. 1996, 229, 334-340. [CrossRef] [PubMed]

32. Aro, E.M.; Virgin, I.; Andersson, B. Photoinhibition of Photosystem II. Inactivation, protein damage and turnover. Biochim. Biophys. Acta 1993, 1143, 113-134. [CrossRef]

33. Mulo, P.; Sakurai, I.; Aro, E.M. Strategies for $p s b A$ gene expression in cyanobacteria, green algae and higher plants: From transcription to PSII repair. Biochim. Biophys. Acta Bioenerg. 2012, 1817, 247-257. [CrossRef] [PubMed]

34. Schroda, M.; Vallon, O.; Wollman, F.A.; Beck, C.F. A chloroplast-targeted heat shock protein 70 (HSP70) contributes to the photoprotection and repair of photosystem II during and after photoinhibition. Plant Cell 1999, 11, 1165-1178. [CrossRef] [PubMed] 
35. Yokthongwattana, K.; Chrost, B.; Behrman, S.; Casper-Lindley, C.; Melis, A. Photosystem II damage and repair cycle in the green alga Dunaliella salina: Involvement of a chloroplast-localized HSP70. Plant Cell Physiol. 2001, 42, 1389-1397. [CrossRef] [PubMed]

36. Rippka, R.; Deruelles, J.; Waterbury, J.B.; Herdman, M.; Stanier, R.Y. Generic Assignments, Strain Histories and Properties of Pure Cultures of Cyanobacteria. Microbiology 1979, 111, 1-61. [CrossRef]

37. Fuhrmann, E.; Gathmann, S.; Rupprecht, E.; Golecki, J.; Schneider, D. Thylakoid Membrane Reduction Affects the Photosystem Stoichiometry in the Cyanobacterium Synechocystis sp PCC 6803. Plant Physiol. 2009, 149, 735-744. [CrossRef]

38. Fuhrmann, E.; Bultema, J.B.; Kahmann, U.; Rupprecht, E.; Boekema, E.J.; Schneider, D. The Vesicle-inducing Protein 1 from Synechocystis sp PCC 6803 Organizes into Diverse Higher-Ordered Ring Structures. Mol. Biol. Cell 2009, 20, 4620-4628. [CrossRef]

39. Porra, R.J.; Thompson, W.A.; Kriedemann, P.E. Determination of Accurate Extinction Coefficients and Simultaneous-Equations for Assaying Chlorophyll-a and Chlorophyll-B Extracted with 4 Different Solvents-Verification of the Concentration of Chlorophyll Standards by Atomic-Absorption Spectroscopy. Biochim. Biophys. Acta 1989, 975, 384-394. [CrossRef]

40. Murchie, E.H.; Lawson, T. Chlorophyll fluorescence analysis: A guide to good practice and understanding some new applications. J. Exp. Bot. 2013, 64, 3983-3998. [CrossRef]

41. van Kooten, O.; Snel, J.F. The use of chlorophyll fluorescence nomenclature in plant stress physiology. Photosyn. Res. 1990, 25, 147-150. [CrossRef] [PubMed]

42. Salvucci, M.E.; Crafts-Brandner, S.J. Relationship between the heat tolerance of photosynthesis and the thermal stability of rubisco activase in plants from contrasting thermal environments. Plant Physiol. 2004, 134, 1460-1470. [CrossRef] [PubMed]

43. Asadulghani, M.; Suzuki, Y.; Nakamoto, H. Light plays a key role in the modulation of heat shock response in the cyanobacterium Synechocystis sp PCC 6803. Biochem. Biophys. Res. Commun. 2003, 306, 872-879. [CrossRef]

44. Murakami, A.; Fujita, Y. Regulation of Stoichiometry between PsI and PsII in Response to Light Regime for Photosynthesis Observed with Synechocystis Pcc-6714-Relationship between Redox State of Cyt B6-F Complex and Regulation of Psi Formation. Plant Cell Physiol. 1993, 34, 1175-1180.

45. Muramatsu, M.; Hihara, Y. Transcriptional regulation of genes encoding subunits of photosystem I during acclimation to high-light conditions in Synechocystis sp. PCC 6803. Planta 2003, 216, 446-453. [CrossRef]

46. Hihara, Y.; Sonoike, K.; Ikeuchi, M. A novel gene, $p m g$ A, specifically regulates photosystem stoichiometry in the cyanobacterium Synechocystis species PCC 6803 in response to high light. Plant Physiol 1998, 117, 1205-1216. [CrossRef]

47. Muramatsu, M.; Hihara, Y. Acclimation to high-light conditions in cyanobacteria: From gene expression to physiological responses. J. Plant Res. 2012, 125, 11-39. [CrossRef]

48. Fraser, J.M.; Tulk, S.E.; Jeans, J.A.; Campbell, D.A.; Bibby, T.S.; Cockshutt, A.M. Photophysiological and photosynthetic complex changes during iron starvation in Synechocystis sp. PCC 6803 and Synechococcus elongatus PCC 7942. PLoS ONE 2013, 8, e59861. [CrossRef]

49. Jordan, P.; Fromme, P.; Witt, H.T.; Klukas, O.; Saenger, W.; Krauss, N. Three-dimensional structure of cyanobacterial photosystem I at 2.5 angstrom resolution. Nature 2001, 411, 909-917. [CrossRef]

50. Guskov, A.; Kern, J.; Gabdulkhakov, A.; Broser, M.; Zouni, A.; Saenger, W. Cyanobacterial photosystem II at 2.9-A resolution and the role of quinones, lipids, channels and chloride. Nat. Struct. Mol. Biol. 2009, 16, 334-342. [CrossRef]

51. Rakhimberdieva, M.G.; Vavilin, D.V.; Vermaas, W.F.J.; Elanskaya, I.V.; Karapetyan, N.V. Phycobilin/ chlorophyll excitation equilibration upon carotenoid-induced non-photochemical fluorescence quenching in phycobilisomes of the Synechocystis sp PCC 6803. Biochim. Biophys. Acta 2007, 1767, 757-765. [CrossRef] [PubMed]

52. Tamary, E.; Kiss, V.; Nevo, R.; Adam, Z.; Bernat, G.; Rexroth, S.; Rogner, M.; Reich, Z. Structural and functional alterations of cyanobacterial phycobilisomes induced by high-light stress. Biochim. Biophys. Acta Bioenerg. 2012, 1817, 319-327. [CrossRef] [PubMed]

53. Biggins, J.; Bruce, D. Regulation of Excitation-Energy Transfer in Organisms Containing Phycobilins. Photosyn. Res. 1989, 20, 1-34. [CrossRef] [PubMed] 
54. Chang, L.; Liu, X.; Li, Y.; Liu, C.-C.; Yang, F.; Zhao, J.; Sui, S.-F. Structural organization of an intact phycobilisome and its association with photosystem II. Cell Research 2015, 25, 726-737. [CrossRef]

55. Emlyn-Jones, D.; Ashby, M.K.; Mullineaux, C.W. A gene required for the regulation of photosynthetic light harvesting in the cyanobacterium Synechocystis 6803. Mol. Microbiol. 1999, 33, 1050-1058. [CrossRef]

56. Mullineaux, C.W.; Emlyn-Jones, D. State transitions: An example of acclimation to low-light stress. J. Exp. Bot. 2005, 56, 389-393. [CrossRef]

57. Kopecna, J.; Komenda, J.; Bucinska, L.; Sobotka, R. Long-term acclimation of the cyanobacterium Synechocystis sp. PCC 6803 to high light is accompanied by an enhanced production of chlorophyll that is preferentially channeled to trimeric photosystem I. Plant Physiol. 2012, 160, 2239-2250. [CrossRef]

58. Komenda, J.; Tichy, M.; Prasil, O.; Knoppova, J.; Kuvikova, S.; de Vries, R.; Nixon, P.J. The exposed N-terminal tail of the D1 subunit is required for rapid D1 degradation during photosystem II repair in Synechocystis sp PCC 6803. Plant Cell 2007, 19, 2839-2854. [CrossRef]

59. Silva, P.; Thompson, E.; Bailey, S.; Kruse, O.; Mullineaux, C.W.; Robinson, C.; Mann, N.H.; Nixon, P.J. FtsH is involved in the early stages of repair of photosystem II in Synechocystis sp PCC 6803. Plant Cell 2003, 15, 2152-2164. [CrossRef]

60. Baker, N.R. Chlorophyll fluorescence: A probe of photosynthesis in vivo. Annu. Rev. Plant Biol 2008, 59, 89-113. [CrossRef]

61. Niyogi, K.K.; Truong, T.B. Evolution of flexible non-photochemical quenching mechanisms that regulate light harvesting in oxygenic photosynthesis. Curr. Opin. Plant Biol. 2013, 16, 307-314. [CrossRef]

62. Campbell, D.; Bruce, D.; Carpenter, C.; Gustafsson, P.; Oquist, G. Two forms of the photosystem II D1 protein alter energy dissipation and state transitions in the cyanobacterium Synechococcus sp PCC 7942. Photosyn. Res. 1996, 47, 131-144. [CrossRef] [PubMed]

63. Santabarbara, S.; Villafiorita Monteleone, F.; Remelli, W.; Rizzo, F.; Menin, B.; Casazza, A.P. Comparative excitation-emission dependence of the $\mathrm{F}_{\mathrm{V}} / \mathrm{F}_{\mathrm{M}}$ ratio in model green algae and cyanobacterial strains. Physiol. Plant 2019, 166, 351-364. [CrossRef] [PubMed]

64. Fulda, S.; Mikkat, S.; Huang, F.; Huckauf, J.; Marin, K.; Norling, B.; Hagemann, M. Proteome analysis of salt stress response in the cyanobacterium Synechocystis sp. strain PCC 6803. Proteomics 2006, 6, 2733-2745. [CrossRef] [PubMed]

65. Mary, I.; Tu, C.J.; Grossman, A.; Vaulot, D. Effects of high light on transcripts of stress-associated genes for the cyanobacteria Synechocystis sp PCC 6803 and Prochlorococcus MED4 and MIT9313. Microbiology 2004, 150, 1271-1281. [CrossRef]

66. Hernandez-Prieto, M.A.; Futschik, M.E. CyanoEXpress: A web database for exploration and visualisation of the integrated transcriptome of cyanobacterium Synechocystis sp. PCC6803. Bioinformation 2012, 8, 634-638. [CrossRef]

67. Sonoike, K.; Hihara, Y.; Ikeuchi, M. Physiological significance of the regulation of photosystem stoichiometry upon high light acclimation of Synechocystis sp PCC 6803. Plant Cell Physiol. 2001, 42, 379-384. [CrossRef]

68. Huang, F.; Parmryd, I.; Nilsson, F.; Persson, A.L.; Pakrasi, H.B.; Andersson, B.; Norling, B. Proteomics of Synechocystis sp. strain PCC 6803: Identification of plasma membrane proteins. Mol. Cell Proteomics 2002, 1, 956-966. [CrossRef]

69. Jansson, C.; Debus, R.J.; Osiewacz, H.D.; Gurevitz, M.; Mcintosh, L. Construction of an Obligate Photoheterotrophic Mutant of the Cyanobacterium Synechocystis 6803: Inactivation of the $p s b A$ Gene Family. Plant Physiol 1987, 85, 1021-1025. [CrossRef]

70. Mullineaux, C.W. Electron transport and light-harvesting switches in cyanobacteria. Front. Plant Sci. 2014, 5, 7. [CrossRef]

(C) 2020 by the authors. Licensee MDPI, Basel, Switzerland. This article is an open access article distributed under the terms and conditions of the Creative Commons Attribution (CC BY) license (http://creativecommons.org/licenses/by/4.0/). 